\title{
Article
}

\section{Forest Exploitation and Wood Supply: A Dendroarchaeological Approach between the Massif Central and the Southern Alps since the Middle Ages}

\author{
Lisa Shindo ${ }^{1, * \mathbb{D}}$, François Blondel ${ }^{2,3}$ and Vincent Labbas 4,5 \\ 1 Cluster of Excellence ROOTS, Christian-Albrechts-Universität zu Kiel, 24118 Kiel, Germany \\ 2 Institute for Environmental Sciences, Université de Genève, 1211 Geneve, Switzerland; \\ francois.blondel@unige.ch \\ 3 UMR629 Chrono-Environnement, 25000 Besancon, France \\ 4 Faculté de Philosophie et lettres, Département des Sciences Historiques, Université de Liège, \\ 4000 Liege, Belgium; vincent.labbas@kikirpa.be \\ 5 KIK-IRPA, 1000 Bruxelles, Belgium \\ * Correspondence: lshindo@roots.uni-kiel.de
}

check for

updates

Citation: Shindo, L.; Blondel, F.;

Labbas, V. Forest Exploitation and Wood Supply: A

Dendroarchaeological Approach between the Massif Central and the

Southern Alps since the Middle Ages.

Forests 2022, 13, 275. https://

doi.org/10.3390/f13020275

Academic Editors: Tomasz Wazny

and Ignacio García-González

Received: 24 December 2021

Accepted: 6 February 2022

Published: 9 February 2022

Publisher's Note: MDPI stays neutral with regard to jurisdictional claims in published maps and institutional affiliations.

Copyright: () 2022 by the authors. Licensee MDPI, Basel, Switzerland. This article is an open access article distributed under the terms and conditions of the Creative Commons Attribution (CC BY) license (https:// creativecommons.org/licenses/by/ $4.0 /)$.

\begin{abstract}
Numerous dendroarchaeological studies have been carried out in buildings in the southeastern quarter of France, which has enabled us to lay the foundations for a first regional restitution of forest stands in the medieval and modern periods, based on the species, diameters, ages and growth rhythms of the trees used by humans. The 2369 pieces of dated softwood timber are mainly larch and fir from the Massif Central and the Alps mountains. Larch seems to have been used mostly locally in the Alps, whereas fir was certainly exported from the two regions to the lowland towns. Very little felling has been identified in the historically troubled 13th-14th century. For the moment we have not identified any fir trees used before the 15th century in the Alps, whereas they are present in the Massif Central from the 12th century. Growth of fir timbers show little variation over time while larch timbers present an increase in growth between those felled until the 12th century and those felled from the 15th century onwards. Finally, since firs from the Massif Central show a higher age trend than those from the Alps, this can serve as a model for identifying the source forests of the timber used in the Rhône valley.
\end{abstract}

Keywords: dendroarchaeology; fir; larch; Alps; timber; forestry

\section{Introduction}

The restitution of forests on the scale of a site and its surroundings has most often been carried out by dendrochronologists for the protohistoric period and from waterlogged wood. The most famous examples concern the palafittic sites established around the lakes and marshes of the Alps and classified by Unesco (https:/ / palafittes.org/homepage.html, accessed on 20 December 2021). Several of them have yielded up to several thousand pieces of wood in some cases [1-4]. The abundance of well-preserved, synchronous timber makes it possible to reconstruct the evolution of the appearance of the source forests as well as the silvicultural practices. By extension, it makes it possibleto trace the human impact on the environment. However, to our knowledge, there are no studies on these issues over large areas for the medieval and modern periods. Two difficulties may explain this: (i) less archaeological wood on a site scale because it is less collected due to a lack of time and money or less well preserved, and, consequently, (ii) a large predominance of large archaeological timber, selected by humans and therefore less representative of the whole forest. Certain textual sources and graphic documents, which are not available for the Protohistory, provide us with additional information. However, knowledge of the appearance of the forests (dimensions and age of the trees in particular) and silvicultural 
practices (leading to the closure and opening of the environments) often remains poorly informed for the medieval and modern periods, particularly on a regional scale. A large set of dendrochronological data from buildings in the south of France finally allow us to provide answers to the issue of forest exploitation and wood supply, and also to understand some of the anthropogenic factors behind the appearance of today's forests.

A particularity of these data is that they are composed of both timbers used in the mountains, close to the source forests [5-12] but also timbers that were exported to the lowland cities $[13,14]$. Indeed, since at least antiquity, humans have transported timber from the mountain forests to the lowland towns (see, for example, [15-19]). One of the main reasons is the law of supply and demand: there was quality timber in the mountain forests and a high demand in the lowland towns to construct and restore buildings. These lowland towns were poor in valuable forests due to their surrounding environment dedicated to agro-pastoral activities which led to early deforestation. The timber trade was almost exclusively upstream to downstream. Wood was mainly transported by water in the form of rafts of floated on "lost logs" because it required less energy and was faster and cheaper than by land [20-25]. In port cities, timber was also widely used for shipbuilding but that is a separate issue and we have chosen to focus here on the buildings.

For some of our archaeological sites on the plains, it is difficult to establish the trade routes and to know from which mountain region the wood that was used came. However, given that a large part of our data clearly comes from the Massif Central or the Alps, this is an opportunity to describe the characteristics of the trees that grew there. Thus, we can obtain a tool to characterise the supply routes for timber and the interrelation between towns, countryside and forests.

\section{Material and Methods}

The geographical areas selected are the Massif Central and the southern French Alps, and their piedmont plains, in Southern France. They are two mountainous massifs, separated by the Rhône axis, a valley structuring the physical and economic landscape for past and present societies [26,27]. These mountainous areas are home to forests of resinous trees like larch (Larix decidua Mill.), fir (Abies alba Mill.), Scots pine (Pinus sylvestris L.), Cembro pine (Pinus cembra L.) and spruce (Picea abies L.). Today, fir and Scots pine are present in the forests of the Massif Central and the Alps, while larch grows only in the Alps (Figure 1). These three species grow at different altitudes, firstly Scots pine (between 400-2000 m a.s.l.) and fir (400-1800 m. a.s.l.) and then larch at the highest altitudes (1200-2400 m. a.s.l., [28]). We investigated different kinds of buildings. Some were still occupied, others were abandoned or in ruins. Their common feature is that they all retained resinous timber in their structures, which we collected.

The dendroarchaeological samples were taken during research programmes and during archaeological prescriptions, before restoration work, for example. Two hundred and seventy-nine built sites have therefore been sampled for dendrochronology.

We sampled 2369 archaeological timbers in total: 1577 larches, 671 firs, 97 Scots pines, 17 Cembro pines and seven spruces. We used a Pressler manual increment borer (Haglöf company, Långsele, Sweden), a Berliner Dendro-Bohrer or a Rinntech electric core drill (respectively, PFUNDT-Schneidwerkzeugmechnik company in Berlin and Rinntech company in Heidelberg Germany), and sometimes, when timbers were removed from the structure, a section was cut with a chainsaw.

In the laboratory, wood species were determined [29] and ring-widths were measured using the incremental measuring table LINTAB and TSAP-Win software [30] or CDendro and CooRecorder program (Cybis company, Saltsjöbaden, Sweden) with $0.01 \mathrm{~mm}$ accuracy. In each case, several rays per sample were measured and then averaged in order to obtain suitable dating series. Then, with different dendroarchaeological software (DENDRON IV, [31] and SYLPHE, [32]), tree-ring series were indexed using the "Corridor", a polynomial indexation which takes into account the amplitudes of the inter-annual variations while preserving the average frequency variations ([31,33] in French; and presentation in English 
in [34]), or the "Except from Besançon", a seven-year moving average that does not take into account the largest and smallest rings, and the ring to be corrected in the calculation of the average [35].

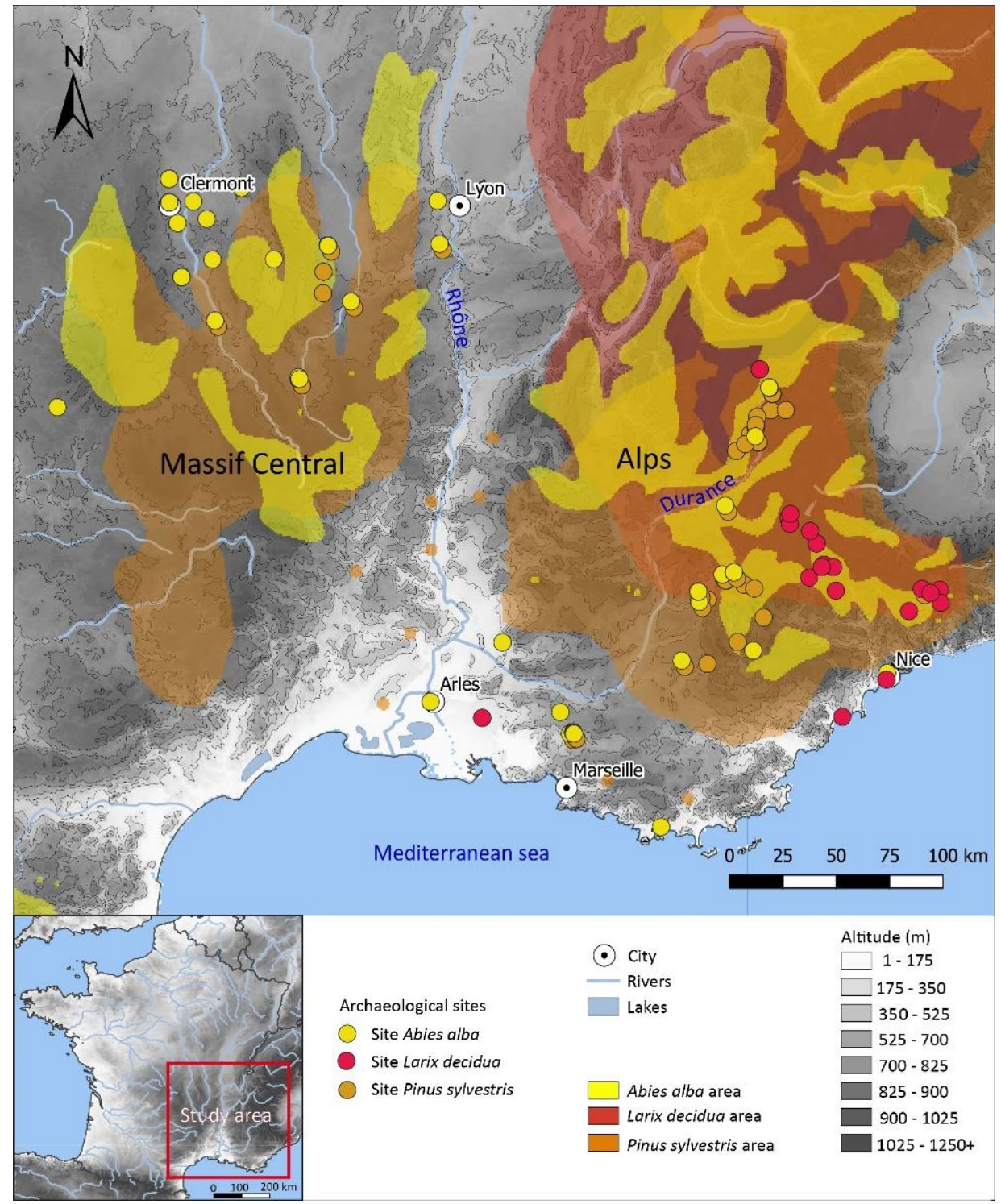

Figure 1. Map of the 279 archaeological sites (circles) represented with their predominant species (fir, larch or Scots pine). In the background, the current cover of forest stands.

Once indexed, the curves were cross-dated using the Student test $(t)$. This parametric test, widely used in mathematics and archaeology, is used to compare two continuous quantitative series [36-39]. It indicates the degree of affinity between two dendrochronological series based on a correlation coefficient. In dendroarchaeology, there is no minimum threshold set for the $t$ value for a result to be considered acceptable. Each synchronisation is different. As a general rule, values above five are adopted and those between three and five are considered on the basis of the replication of results.

On our samples, not all piths are present, but in the vast majority of cases few or no rings are missing. As the height of the sample in the tree is not exactly known, the juvenile phase may be truncated by a few years, even 10 to 20 years. However, given the large dataset at our disposal, the reading and interpretation of the studied parameters is possible.

First, we represented the fir, larch and Scots pine dendrochronological series in a block diagram (there are not enough series of spruce and Cembro pine to make it relevant) 
(Figure 2). Each horizontal bar corresponds to a piece of wood, its length is a function of the number of rings preserved and thus of the age of the tree at the time of felling. These series are arranged according to their felling dates. The curves shown in transparency on the block diagram indicate, for each species, the coverage of the dendrochronological series, that is to say the number of rings available per year. The higher the value, the more data are available for the year in question.

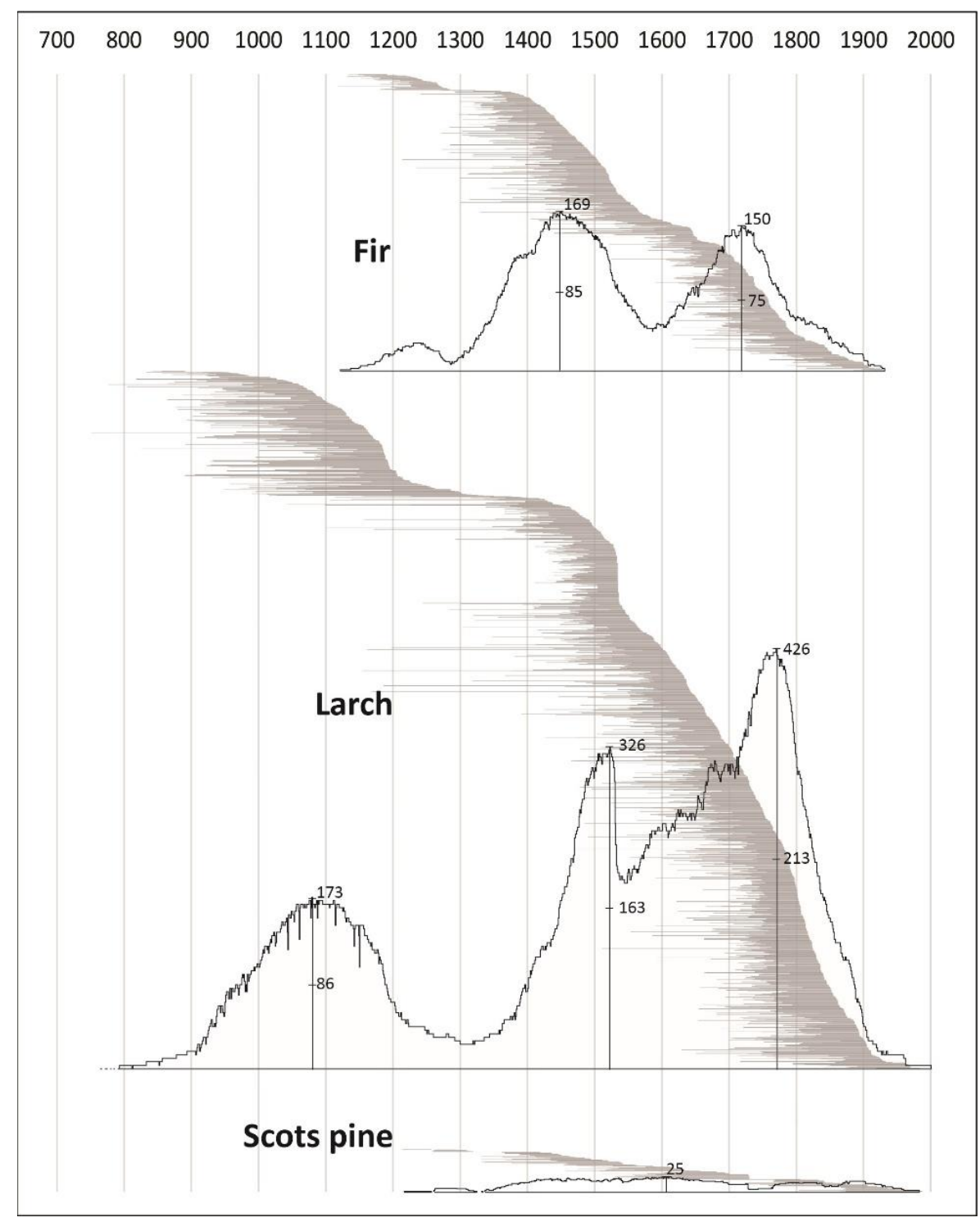

Figure 2. Block diagram of the 2345 individual archaeological series of dated fir, larch and Scots pine, arranged according to the felling dates. Each horizontal bar corresponds to a timber. Their coverings over time (number of rings available per year) are shown on top.

Then, we worked on larch and fir, species for which the number of series is relevant. For these species, we calculated the minimum diameters of the trees as well as their minimum cambial ages (Figure 3) and then, their age trends (Figure 4). In order to be more easily readable, all the age trends were smoothed using 20-year moving averages, which is why the curves only start at the 20th year. To calculate these age trends, trees were grouped by half-century windows, according to the date of the last ring, to make the human selection visible through the felling date. These groups were kept only if the number of trees inside was higher than 40 , explaining periods without age trends. In the last part of the study, we make a geographical comparison between the two regions (Massif 
Central and Alps), using only fir, with all periods combined (Figures 5 and 6). However, in this case we did not calculate fir age trends by the half century because the numbers were insufficient to be representative.

For comparison, we also used dendrochronological series from living trees: 208 series of Alpine larch, 132 series of Alpine fir and 78 series of Massif Central fir. We selected only living trees that started growing from 1850 onwards so that they reflect current growing conditions. Some of these series are published [9,40-42], others are unpublished. However, they all come from our study area and have been shown to be relevant in numerous dendrochronological studies over the last few years by providing accurate dating (The data on live fir trees collected in the Massif Central have not yet been synthesised, but this work is in progress. It takes into account the published data from [43] and also unpublished data from Loïc Francon, Lianne Gouma, Arthur Mathonnat and François Blondel.).

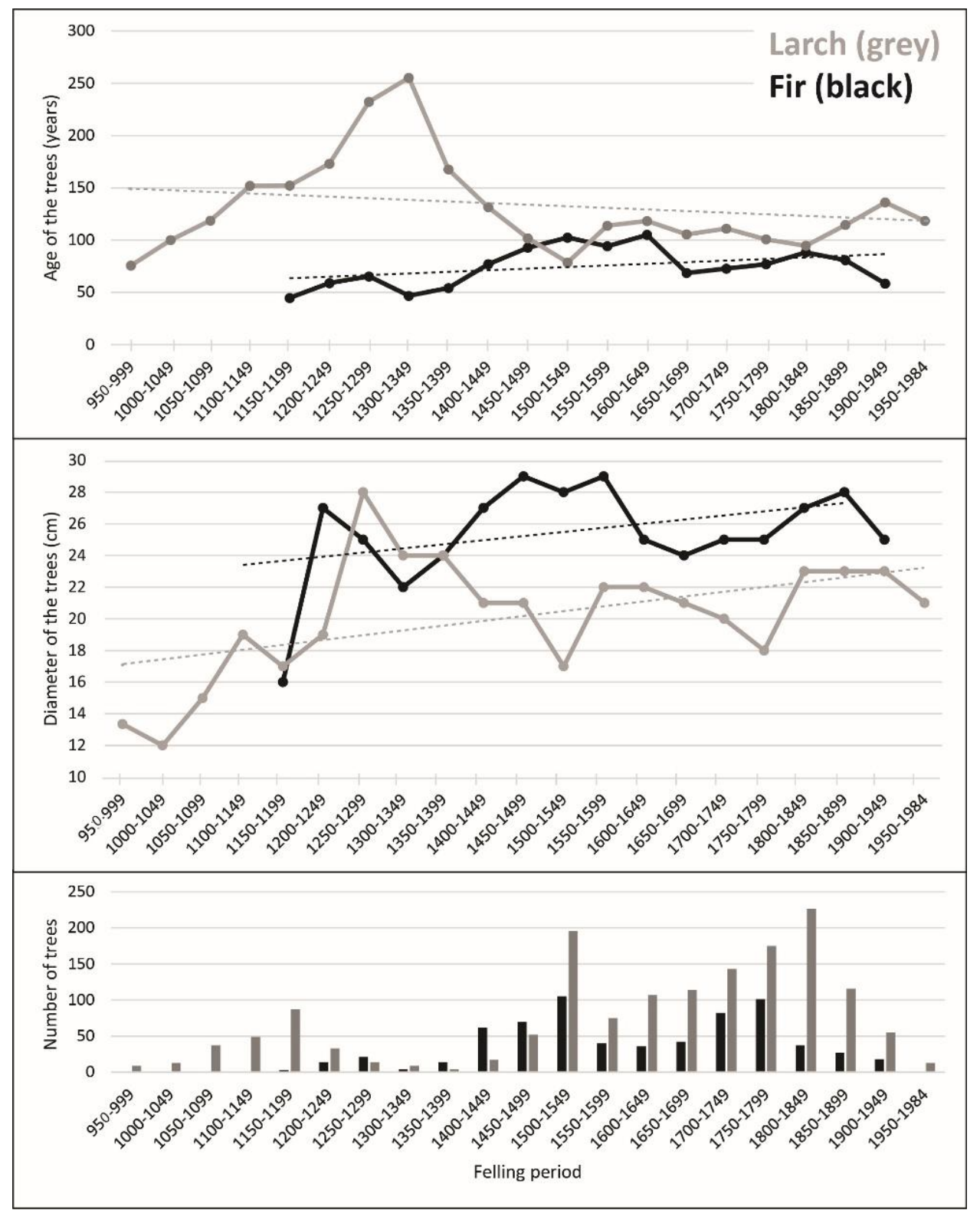

Figure 3. Comparison of the characteristics of archaeological larch (in black) and archaeological fir (in grey) over time. From top to bottom, tree age, tree diameter and number of trees, according to 50 -year time windows based on the date of the last ring. In dotted lines, the associated trend curves. 


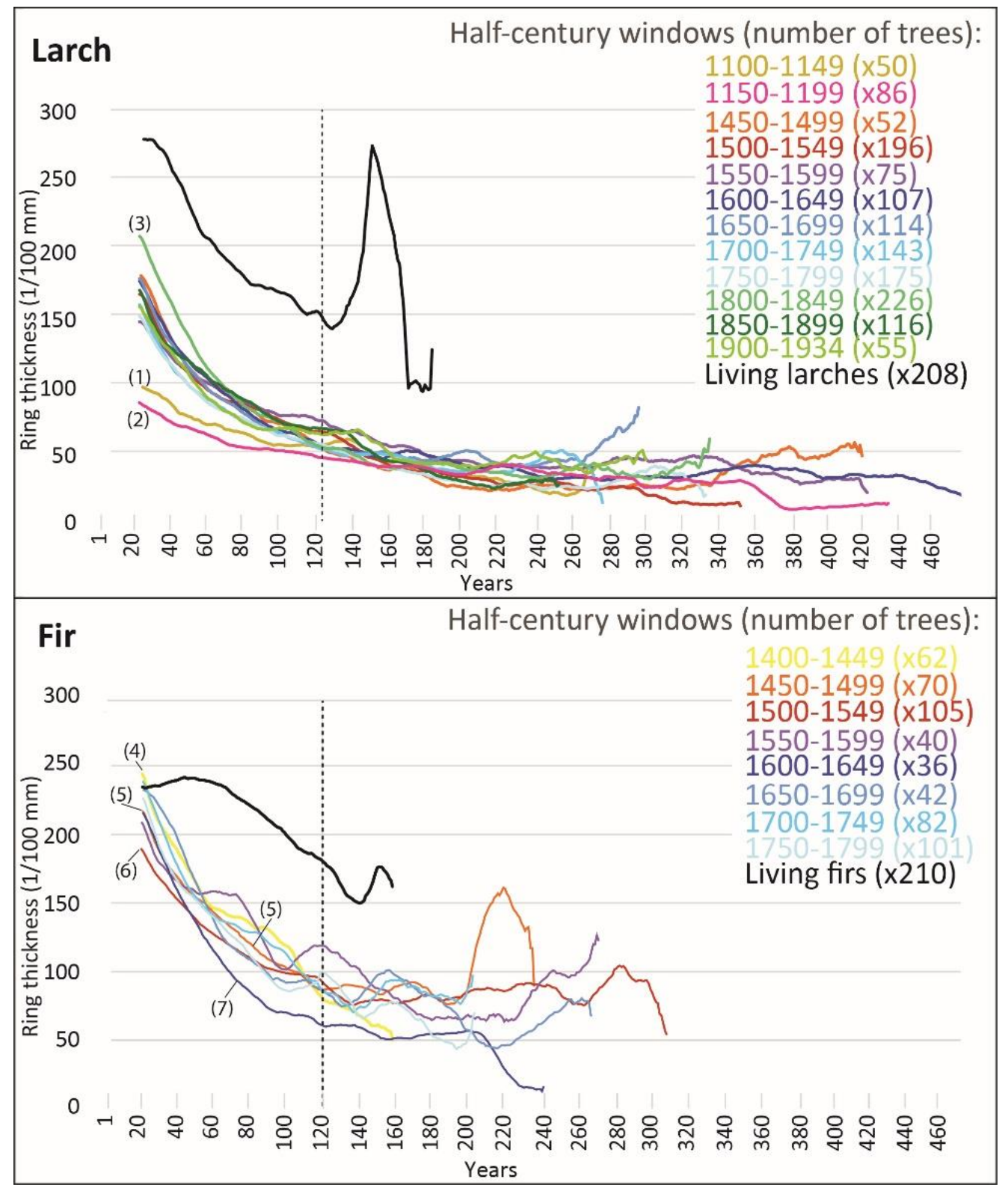

Figure 4. Age trends of archaeological larches (upper part) and firs (lower part) according to 50-year time windows, based on the date of their last ring, each in a different colour. The age trends of the actual trees are shown in black. After the 120th year (vertical dotted line), the age trends are less representative. The small numbers in brackets on the curves refer to explanations in the text. 


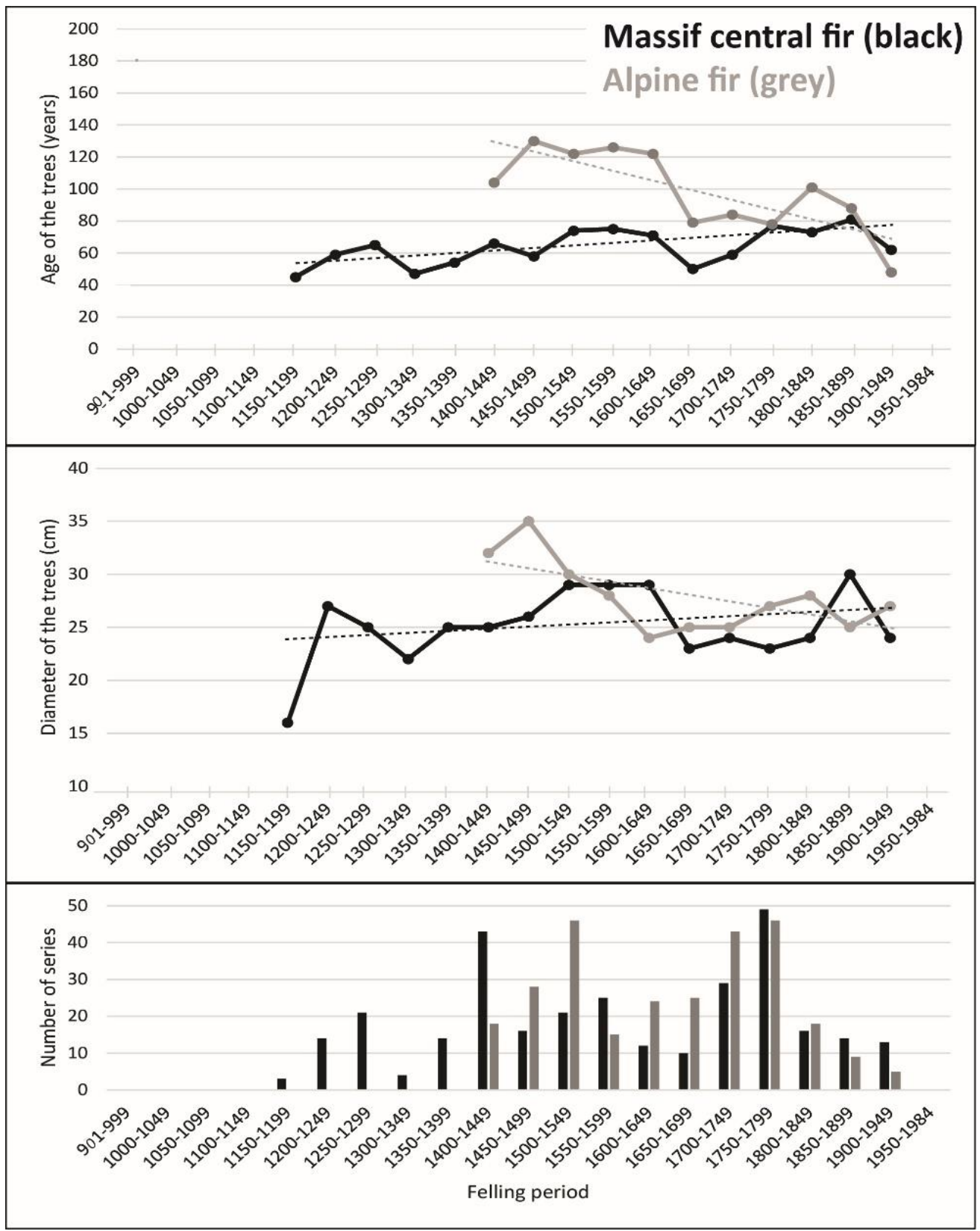

Figure 5. Comparison of the characteristics of archaeological Alpine fir (in grey) and archaeological Massif central fir (in grey) over time. From top to bottom, tree age, tree diameter and number of trees, according to 50-year time windows based on the date of the last ring. In dotted lines, the associated trend curves. 


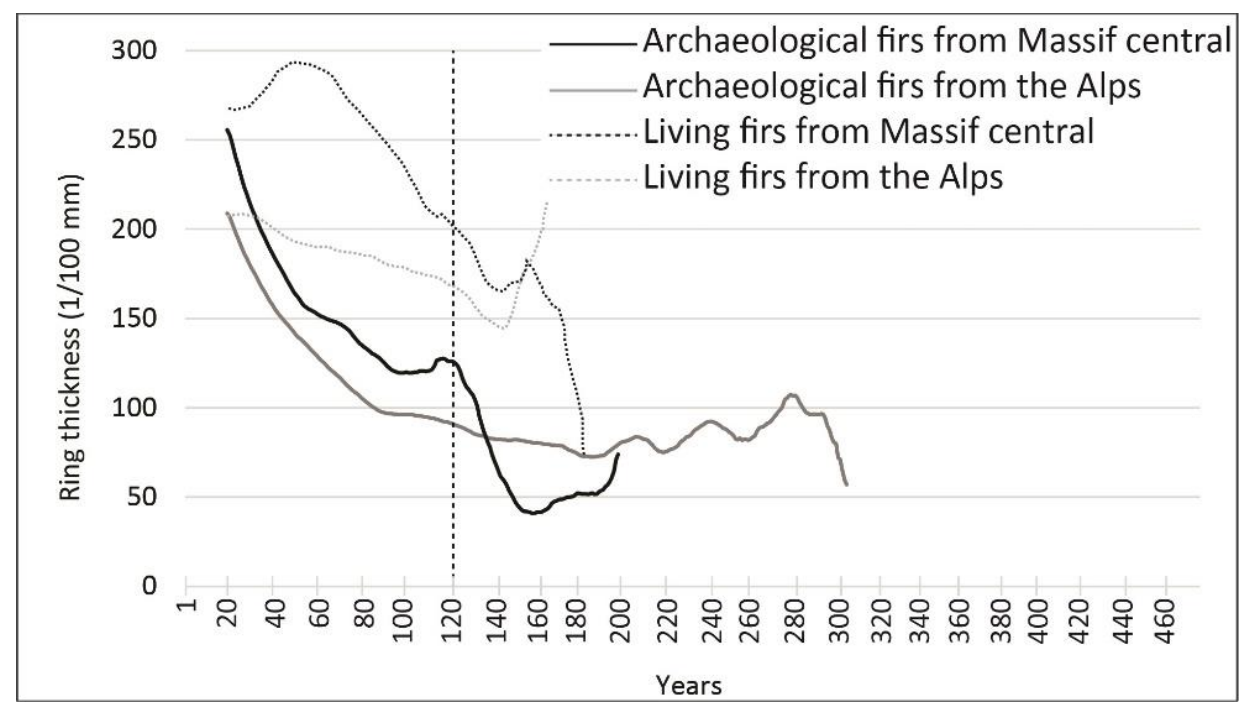

Figure 6. Age trends of Massif Central firs (in black) and Alpine firs (in grey). For comparison, the age trends of the current living trees are shown in dotted curves. After the 120th year (vertical dotted line), the age trends are less representative.

\section{Results}

\subsection{Spatial Distribution of Species Use}

In the past, Scots pine and larch seem to have been used only in sites in the immediate vicinity of their growing areas in the mountains (Figure 1). Nevertheless, this is not entirely true. We have indeed identified larch in two sites close to the Mediterranean Sea, in the cities of Nice and Cannes. We also identified a few beams of Scots pine in buildings in the plain (but these beams are not dated, so they do not appear on the map). Fir is the only species used in abundance both in mountainous areas and in the plains, in buildings close to the rivers Durance (Aix-en-Provence city) and Rhône (Arles city).

\subsection{Felling}

The block diagram (Figure 2) illustrates that there was continuous felling from the 10th century to the present, but little felling from the very end of the 13th to the end of the 14 th century, for both fir and larch. It seems that the same is true for Scots pine, even if the number of trees is too small to be truly representative (only seven pre-15th century Scots pine series).

The coverage of our data (transparent curves on the block diagram) indicates that the mid-15th and early 18th centuries have the most data for the fir series, and the late 11th, early 16 th and mid-18th centuries for larch. This does not necessarily mean that there was a lot of felling in these periods, but only that we have access to a large number of samples for these periods, which are particularly well represented. In contrast, the low number of felling events identified at the end of the 13th-14th century coincides with a low amount of available tree rings.

\subsection{Diameter-Age Correlation}

Over time, the archaeological timbers (larch, fir, Massif Central fir and Alpine fir, Figures 3 and 5) show almost synchronous variations in age and diameter. This means that when age increases, diameter also increases, and vice versa. The two notable exceptions to these synchronous variations are (i) the first half of the 14th century for larch, when the age of the felled larch increased compared to the end of the 13th century, but the diameters decreased and (ii) the first half of the 20th century for Alpine fir, when their ages decreased while their diameters increased compared to the late 19th century. However, in both cases, the number consists of less than ten trees, which should be confirmed by enlarging the sample size. 
If we consider the general trends of these age and diameter variations (dotted lines on Figures 3 and 5), the ages of the larches decrease slightly over time while their diameters increase (Figure 3). This means that younger and younger larches were used, but with increasing dimensions, i.e., larches that grow faster and faster. As for the firs, their ages and diameters increase slightly over time (Figure 4); thus, firs are increasingly older and larger.

\subsection{Types of Growth}

The age trend (Figures 4 and 6) of all trees decreases with age according to a classic process described by many authors for a long time [3,44-46]. After the 120th year (represented by a dotted line in the age trend figures), the number of rings included in the averages decreases significantly and the age trends are less representative. We have chosen to draw them anyway, but we did not take them into account in our reflections.

If we look at the larch (upper part of Figure 4), it is the older trees, from the 12th century that grew the slowest since their age trends (curves (1) and (2)) are lower than all the more recent ones. There is not enough data in the 13 th and early 14 th centuries to calculate age trends so we cannot know how the age trend changed during this time. From the 15th century to the early 20th century, larches grew more rapidly. Of all the archaeological timbers, the larches felled in the first half of the 19th century have the highest age trend (curve (3)). However, it's the current larch trees that are growing the best, better than archaeological timbers.

Concerning fir trees, the age trends of the archaeological timbers are relatively similar over time (lower part of Figure 4), however, there is a progressive decrease in age trends from the 15th to the first half of the 16th century (curves (4), (5) and (6)). Firs felled in the first half of the 17th century (curve (7)) have one of the fastest decreasing age trends: from about their 50th year they show the slowest growth ever. Like the larches, all the archaeological fir trees differ markedly from those of present-day living fir trees.

\subsection{Massif Central et Alpes}

Finally, as fir has been used in the Alps and in the Massif Central, we compared the characteristics of trees from these two regions. Age trends of firs in the Massif Central are higher than in the Alps (Figure 6). Archaeological firs, as present-day living firs, grow faster in the Massif Central than in the Alps. From an archaeological point of view, fir seems to have been used formerly in the Massif Central (from the 12th century) and it appears in Alpine buildings from the 15th century (Figure 5). From the 16th century onwards, fir diameters are comparable in both regions, but Alpine firs are older than Massif Central firs (Figure 5).

\section{Discussion}

Our current vision of the use of timber in the past is truncated because we can only study the timber that has been preserved up to now, and the timber which we sampled. Moreover, some areas are investigated more than others according to the opportunities that are offered (see Figure 1), such as certain Alpine valleys (Clarée, Bléone and Tinée) or certain urban areas (Clermont-Ferrand in the Massif Central, Aix-en-Provence in the plain). However, it is a constant issue in archaeology, trying to be as exhaustive as possible with necessarily incomplete data.

\subsection{Locally Used and Exported Species}

In the Massif Central, fir is the most commonly used wood for buildings, while larch is the most common in the Southern Alps (Figure 1). These trees were widely used in construction in the two massifs since the Middle Ages for their straightness and good mechanical properties [47]. Thus, they were employed for the structural parts of buildings, such as walls, partitions, floors and roofs. Spruce was used very little because it was not present before the 19 th century plantations $[48,49]$. Other resinous species used in construction at high altitudes are: Scots pine in the Massif Central, fir, stone pine and Scots 
pine in the Alps. These species are not visible on the map because they are in minority or not dated. If we go down in altitude, we find fir and Scots pine buildings in the pre-Alps. Then, on the plains, the buildings studied seem to be made only of fir. However, it should be noted that Scots pine is also used to some extent, but as it is still difficult to date due to a lack of reference material, so it does not appear systematically on the map. If mountain fir and Scots pine were certainly exported to lowland towns (see for example [14]), this was also the case for the larch. Larch is mainly found in the cities of the south-east, in the Alpes-Maritimes [13,50]. Anthropogenic pressure is constant at high altitude [51-53], limiting wooded areas to those that are steep, difficult to access and unsuitable for agropastoral activities. Ancient texts and archaeological findings attest to the exportation of Alpine larch to the plains in ancient times for shipbuilding $[15,54]$ and in medieval times for building [17]. One may therefore wonder why it is so little visible today. This may be due to an architectural reality where larch is not used as much as it used to be, a lack of sampling in these lowland buildings and/or the disappearance of these larch elements following restoration.

\subsection{Little Felling in the 14th Century}

While there has been continuous felling from the 10th century to the present day, the 14th century is an exception. This hiatus in the 14th century has already been documented for Alpine larch [55], but it also seems to exist for fir, and perhaps for Scots pine, even if the number of the latter species is too low at the moment. This low number of fellings may be linked to the decrease in the number of new constructions and therefore to the demographic and economic conditions of the time. Indeed, this period was marked by wars, famines and epidemics [7,56-59]. Moreover, F. C. Ljungqvist et al. [60] have shown that this hiatus also existed on a European scale and that it was linked to the plague episodes. This is therefore a period when the rate of new construction was clearly slowed down by a fall in population, thereby limiting the exploitation and the need for timber.

Paradoxically, although the dendro-archaeological data indicate a drop in felling from the second third of the 14th century, the written records nevertheless reveal frequent logging in this time period $[17,61]$. However, this exploitation can be tempered by the fact that it is perceived through restrictions on felling [27,61]. It may have taken some time to be applied in practice, especially in the rural areas of the medium and high mountains. These restrictions are found in the texts both in the mountains [27] and in the plains [61].

\subsection{Assumptions and Attempts to Reconstruct Silvicultural Practices}

In our opinion, the variation in the diameters of harvested trees reflects the state of openness or closure of the environment. In fact, in open environments, diameters tend to increase, whereas in closed environments they tend to decrease. The age of the trees at the time of felling only reflects the time at which humans decided to fell them, it is not a selection criterion [62]. From the dendro-archaeological data, it seems impossible to say whether they were deliberately preserved or spared until they were felled.

The diameter and age variations of our archaeological wood are on the whole synchronous over time (diameter and age increase or decrease simultaneously). Higher values reflect indeed an opening of the environment and cutting of older trees, whereas lower values reflect a closing of the environment and cutting of younger trees. One might have expected younger trees to be felled in open areas because they grow faster (and conversely, older trees to be felled in closed areas because they grow slower), but this is not what our data showed. One explanation for this phenomenon would be a certain time lag between the causes that led to the appearance of a forest (such as population and felling increases) and the effects on trees felled later in the same forest, which have been preserved to our day (see e.g., [63] who studied old trees in open areas).

The fact that in the first half of the 16th century the larches and Alpine firs used in the constructions have smaller diameters and are younger than those used before may therefore reflect a closure of the environment and the selection of younger trees (Figure 3). 
However, this could coincide with history. After the troubles of the Hundred Years' War (a succession of conflicts between France and England during the 14th and the 15th centuries), the population decreased and the forestry exploitation was reduced [64]. As a result, the forests became denser [65] and may have closed. On the other hand, the fir trees used in the Massif Central at the same time show an opposite profile: larger diameters and ages, i.e., forests that are opening up and less frequent felling. This is confirmed by pollen studies carried out in several places in the Massif Central, which indicate a clear decline in forest areas in favour of the extension of agro-pastoral activities [51,53]. The highland landscape is therefore open with heterogeneous forest areas.

The larch trees felled in the 12th century had the greatest difficulty in growing, but this low growth rate was never reached again afterwards (see curves (1) and (2) on Figure 4). These trees began to grow between 751 and 1150, i.e., during a period with cold summers in the French Alps, particularly around 840, 950, 1020 and 1120. This also corresponds to the Oort solar minimum between 1040 and 1080 [66]. This difficult climatic period does not seem to have been favourable to the growth of Alpine larches.

The number of larch trees felled in the 13th and 14th centuries that have been preserved is very small (this is why their age trends have not been calculated). The 13th century corresponds to a period of overexploitation of forests in the Massif Central [67] and to a decrease in forest species associated with an increase in cultivation in the Alps [49]. However, the diameters and ages of the larches from this period suggest that these trees, which were used during this troubled period, were particularly large and old (Figure 3). Nevertheless, this does not mean that all of the larches of that time were like this. The large size of the preserved larches may explain why they have been conserved in the buildings to this day, contrary to the smaller wood, which are more sensitive to erosion and more easily used as fuel, and whose preservation over the centuries is less obvious.

The best growth of archaeological larches is in those felled in the first half of the 19th century (1800-1849), at least until they are 60 years old (see curve (3) on Figure 4). These larches are also the ones with the largest diameters since medieval times, as well as relatively low ages. The majority of these larches started to grow between 1720 and 1740 , so until 1780-1800, i.e., during their first 60 years of life, their growth conditions were very favourable. There are historical reasons for this. Indeed, the 18th century saw the intensification of forestry regulations with, for example, the obligation to restock the forests of Briançon in 1723 [68] and the "Réformation des Eaux et Forêts", i.e., the inspection of the state of the forests in 1725, which led to felling bans [64]. This seems to have been a favourable period for the growth of young larches, which were felled about a hundred years later, in the first half of the 19th century.

As for the fir trees, their age trends over time show little variation, so it seems that these trees grew in a relatively similar way from the 15th to the 18th century (Figure 4 ). The slight decrease in age trends between the early 15th century and the first half of the 16th century (curves (4), (5) and (6)) is difficult to explain with our current knowledge. As early as antiquity and the Middle Ages in the Massif Central, following the overexploitation of forests at lower altitudes and the development of agro-pastoral activities, humans went to fell trees at higher altitudes [69-71]. If we consider the same case for the 15th to the 16th century, this would explain the presence of fir trees with increasingly slow growth as humans came to exploit them at higher and higher altitudes and the growing conditions up there were more difficult. It was in fact from the 16th century onwards that several pieces of legislation testify to the growing concern of the Royal power for the protection of forests. The latter is often linked to the acceleration of deforestation [64].

The numerous conflicts of the 17th century generated a very high demand for wood, especially for war fleets. It might explain why the archaeological firs felled in the first half of the 17th century (curve (7) in Figure 4) have the slowest growth of all those studied. They might have been taken from previously preserved highland and/or closed forests [72].

In general, between the 12th century and the beginning of the 20th century, the fact that the archaeological fir trees were larger and older (Figure 3), could therefore be explained by 
the felling of old fir trees growing in increasingly open environments. Since access to the resource is easier than in dense and closed environments, a better selection of fir trees to be felled is therefore possible.

\subsection{Massif Central and Alps}

The use of fir in Alpine buildings, more than two centuries later than in the Massif Central, can of course be explained by a bias in our Alpine data. However, it may also be a reality. Fir is attested to in the Alpine pollinic diagrams as early as 4686-4369 Cal BC [49], although in smaller quantities than larch and especially pine. Then also, according to palynological analyses, fir stands were destroyed between the 9th and 11th-13th centuries in some areas of the southern Alps [73]. The firs first used in the southern Alps in the 15th century do not therefore come from completely new stands, some fir trees clusters could have been preserved. In addition to the scarcity of firs from the 13th century onwards [73], a second explanation could be that before the 15th century, fir trees from the southern Alps were mainly used for export [17] and larch was preferentially used in high altitude buildings. Thus, the pre-15th century Alpine fir beams would have disappeared during the major modern restorations of lowland buildings, as in the 17th and 18th centuries in Aix-en-Provence [14].

In general, firs in the Massif Central grow faster than those in the Alps: they have similar diameters, but are felled younger than the Alpine firs, and this is reflected in their higher age trends (Figure 6). Fir exploitation may have been more intensive in the Massif Central than in the Alps. There may also have been more favourable growing conditions in the Massif Central. However, we do not know whether these are solely environmental, in particular by taking into account the altimeter factor, or whether they have been favoured by silvicultural practices, such as opening up the environment. Synthesis analyses for softwoods, and in particular fir, are still lacking for the Massif Central.

An application of this distinction could be a dendro-provenance tool. For example, the fir trees used in the lowland buildings of the lower Rhone valley, such as in Avignon city [22], can come from both the Massif Central and the Alpine forests. Their age trends could thus be a good tool for hypothesising their provenance.

\section{Conclusions}

At the end of this study, there are three perspectives envisaged. The first concerns the need to carry out specific dendroarchaeological research in the range of the Alpine fir, i.e., in the montane level, in order to confirm or disprove its absence in buildings before the 15th century. The second perspective would be to provide better information on silvicultural practices based on the timber (Scots pine and fir) for the Massif Central area. The comparison of dendrochronological corpuses has indeed shown a data gap between the Massif Central and the Alps. The third perspective would be a detailed study of the characteristics of the wood used in different types of buildings, according to their location (rural or urban) and their category (civil or religious). This would allow the identification of potential differences in supply and quality, depending on the final destination of the timber.

Author Contributions: L.S. prepared and analysed the data, wrote and proofread the article. F.B. prepared and analysed the data, wrote and proofread the article. V.L. prepared and analysed the data, wrote and proofread the article. All authors have read and agreed to the published version of the manuscript.

Funding: This research was founded of the Deutsche Forschungsgemeinschaft (DFG, German Research Foundation) under Germany's Excellence Strategy_EXC 2150 ROOTS-390870439.

Institutional Review Board Statement: Not applicable.

Informed Consent Statement: Not applicable.

Data Availability Statement: Not applicable. 


\begin{abstract}
Acknowledgments: The authors thank all the researchers who worked before them and who made this regional synthesis possible (they are gathered under the symbolic figure of Camille Noûs, who embodies the contribution to research of the community as a whole. Camille Noûs, from Cogitamus Laboratory, claims the collaborative and open nature of knowledge creation, appraisal and dissemination, under the control of the academic community). We particularly thank the dendrochronologists who gave us access to their data. Thanks to Emma Moreau for the English revision.
\end{abstract}

Conflicts of Interest: The authors declare no conflict of interest.

\title{
References
}

1. Winiger, A. La Station Lacustre de Concise 1, Statigraphie, Datations et Contexte Environnemental; Cahiers D'archéologie Romande: Lausanne, Switzerland, 2008.

2. Bleicher, N. Altes Holz in Neuem Licht. Archäologische und Dendrochronologische Untersuchungen an Spätneolithischen FeuchtbodenSiedlungen in Oberschwaben. Berichte zu Ufer- und Moorsiedlungen Südwestdeutschlands V (Materialh Archäol Baden-Württ 83); Theiss: Stuttgart, Germany, 2009.

3. Billamboz, A. Dendroarchéologie et écologie des palafittes. In La Dendroécologie; Payette, S., Filion, L., Eds.; Presses de l’Université de Laval: Laval, QC, Canada, 2010; pp. 509-536.

4. Billamboz, A.; Martinelli, O. Dendrochronology and Bronze Age pile-dwellings on both sides of the Alps: From chronology to dendrotypology, highlighting settlement developments and structural woodland changes. In The End of the Lake-Dwellongs in the Cirum-Alpine Region; Menotti, F., Ed.; Oxbow Books: Barnsley, UK, 2015; pp. 68-84.

5. Boccaleri, E. Dendrocronologia per l'archeologia e la storia del Villagio. Il caso di Carnino. Riv. Studi Liguri 1985, 1, $224-236$.

6. Orcel, A.; Orcel, C. La datation dendrochronologique de 41 constructions de la Villa di Dagro. Bull. Cent. Genev. D'anthropologie 1988, 1, 104-112.

7. Phalip, B. Charpentes et Couvreurs. L'auvergne Médiévale et Ses Marges; Association Lyonnaise Pour la Promotion de L'archéologie en Rhône-Alpes: Lyon, France, 2004.

8. Büntgen, U.; Bellwald, I.; Kalbermatten, H.; Schmidhalter, M.; Frank, D.C.; Freund, H.; Bellwald, W.; Neurevirth, B.; Nüsser, M.; Esper, J. 700 years of settlement and building history in the Lötschental, Switzerland. Erdkunde 2006, 60, 96-112. [CrossRef]

9. Edouard, J.-L. Longue chronologie de cernes du mélèze et occupation humaine depuis plus de mille ans dans la vallée de la Clarée (Briançonnais, Alpes françaises). In Archéologie de la Montagne Européenne, Proceedings of the Actes de la Table Ronde Internationale de Gap, Gap, France, 29 Septembre-1 Octobre 2008; Tzortzis, S., Delestre, X., Eds.; Bibliothèque D'archéologie méditerranéenne et Africaine: Paris, France, 2010; pp. 325-333.

10. Guibal, F.; Meyran, J.-J. Reconstitution de l'habitat de la vallée du Bachelard au cours des derniers siècles par la dendrochronologie. In La Vallée de l'Ubaye: Un Territoire Unique Pour Les Recherches en Géosciences, Proceedings of the Actes du Colloque D'ouverture, Barcelonnette, France, 12-16 Septembre 2011; Mallet, J.-P., Ed.; Editions Association SELOANE: Barcelonnette, France, 2011; pp. 71-72.

11. Labbas, V. Archéologie et Dendrochronologie du Bâti Subalpin Dans le Massif du Mercantour Durant le Second Millénaire de Notre Ere. Ph.D. Thesis, Aix-Marseille Université, Marseille, France, 2016.

12. Shindo, L. Bois de Construction et Ressources Forestières Dans Les Alpes du sud au IIe Millénaire. Dendrochrono-Ecologie et Archéologie. Ph.D. Thesis, Aix-Marseille Université, Marseille, France, 2016.

13. Blanc, F.; Labbas, V. La charpente de l'église "Neuve" de Cannes: Notre-Dame d'Espérance (XVIe-XVIIe siècles). ARCHEAM Bull. Annu. Cercle D'histoire D'archéologie Alpes-Marit. 2016, 21, 40-52.

14. Shindo, L.; Claude, S. Buildings and wood trade in Aix-en-Provence (South of France) during Modern period, TRACE-Tree Rings in Archaeology, Climatology and Ecology. Dendrochronologia 2019, 54, 29-36. [CrossRef]

15. Terrer, D. Etude sur les Bois dans L'antiquité. Master's Thesis, Université de Provence Aix-Marseille I, Marseille, France, 1978.

16. Leroy, P.-M. L'exploitation de la Mâture Dans les Pyrénées, les Grands Classiques du Pyrénéisme; Editions Monhélios, réédition du mémoire de 1776; Couturier Père et Fils: Paris, France, 1988.

17. Bernardi, P. Métiers du bâtiment et Techniques de Construction à Aix-en-Provence à la Fin de l'époque Gothique (1400-1550); Publication de L'université de Provence: Aix-en-Provence, France, 1995.

18. Eißing, T.; Dittmar, C. Timber transport and dendro-provenancing in Thuringia and Bavaria. In Proceedings of the Conference Tree Rings, Art, Archaeology, Brussels, Belgium, 10-12 February 2010; Fraiture, P., Ed.; Scientia Artis 7: Brussels, Belgium, 2011; pp. 137-149.

19. Domínguez-Delmás, M.; Alejano-Monge, R.; Van Daalen, S.; Rodríguez-Trobajo, E.; García-González, I.; Susperregi, J.; Wazny, T.; Jansma, E. Tree-rings, forest history and cultural heritage: Current state and future prospects of dendroarchaeology in the Iberian Peninsula. J. Archaeol. Sci. 2015, 57, 180-196. [CrossRef]

20. Fouilland, S.; Furestier, D. Le flottage sur la Durance et sur l'Isère hier et aujourd'hui. Le Monde alpin et rhodanien. Rev. Régionale D'ethnologie 1999, 1, 55-77.

21. Barruol, G.; Lonchambon, C.; Furestier, D.; Miramont, C. La Durance de Long en Large. Bacs et Radeaux Dans L'histoire d'une Rivière Capricieuse; Editions Alpes de Lumière: Forcalquier, France, 2005. 
22. Bouticourt, E. Charpentes Méridionales: Construire Autrement: Le Midi Rhodanien à la fin du Moyen Age; Honoré Clair: Arles, France, 2016.

23. Eißing, T. Flößerei. Johannesberger Arbeitsblätter, Fulda. Themenbereich 2016, 2, 1-16.

24. Domínguez-Delmás, M.; Van Daalen, S.; Alejano-Monge, R.; Wazny, T. Timber resources, transport and woodworking techniques in post-medieval Andalusia (Spain): Insights from dendroarchaeological research on historic roof structures. J. Archaeol. Sci. 2018, 95, 64-75. [CrossRef]

25. François, A.L. Le flottage du bois sur la Garonne: Archéologie d'un espace économique et d'un savoir-faire (XVIIe-XIXe siècle). In Des Routes et des Homme: La Construction des Echanges par les Itinéraires et les Transports; Lemaitre, N., Ed.; Éditions du Comité des Travaux Historiques et Scientifiques: Aubervilliers, France, 2019. [CrossRef]

26. Blanchard, R. Les Alpes Occidentales, 7, Essai d'une Synthèse; Editions Arthaud, B.: Paris, France, 1956.

27. Boyer, J.-C. Pour une histoire des forêts de Haute Provence (XIIIe-XVe s.). Provence Hist. 1990, 161, $267-290$.

28. Rameau, J.-C.; Mansion, D.; Dumé, G.; Lecointe, A.; Timbal, J.; Dupont, P.; Keller, R. Flore Forestière Française, Guide Ecologique illustré; Institut Pour le Développement Forestier, Ministère de L'agriculture et de la Pêche, Direction de L'espace rural et de la Forêt, Ecole Nationale du Génie Rural Des Eaux et des Forêts: Paris, France, 1993; Volume 2, Montagnes.

29. Schweingruber, F.H. Anatomie europaïscher Hölzer: Ein Atlas zur Bestimmung europaïscher Baum-, Strauch-, und ZwergstrauchhölzerAnatomy of European Woods: An Altas for the Identification of European Trees, Shrubs, and Dwarf Shrubs; Verlag P. Haupt: Bern, Switzerland, 1990.

30. RINNTECH. LINTAB. Precision Ring by Ring. 2014. Available online: http://www.rinntech.com/Products/Lintab.htm (accessed on 20 December 2021).

31. Lambert, G.-N. Dendrochronologie, Histoire et Archéologie, Modélisation du Temps. Le Logiciel Dendron II et le Projet Historik Oaks, V1 et V2; Accreditation to Supervise Research; Université de Franche-Comté: Besançon, France, 2006.

32. Meignier, S. Sylphe: Logiciel D'aide à la Dendrochronologie; Laboratoire de Chrono-Ecologie, Unité Dendrochronologie, UFR Science: Besançon, France; Musée de Neuchatel: Neuchatel, Switzerland, 2001.

33. Durost, S. Dendrochronologie et Dendroclimatologie du 2e âge du Fer et de L'époque Romaine dans le Nord et l'Est de la France. Datation, Système de Références et Modélisation. Ph.D. Thesis, Université de Franche-Comté, Besançon, France, 2005.

34. Shindo, L.; Giraud, E. Well-designed mountain houses feature the only dated Pinus sylvestris type timbers in the southern French Alps, TRACE-Tree Rings in Archaeology, Climatology and Ecology. Dendrochronologia 2021, 67, 125833. [CrossRef]

35. Lambert, G.-N.; Lavier, C. L'étalon de datation dendrochronologique Bourgogne 29, Les veines du temps. In Lecture du Bois en Bourgogne; Editions Musée Rolin: Autun, France, 1992; pp. 123-156.

36. Wilks, S.S. Mathematical Statistics; John Wiley \& Sons: London, UK, 1943.

37. Baillie, M.G.L.; Pilcher, J. A simple crossdating program for Tree-Ring Research. Tree Ring Bull. 1973, 33, 7-14.

38. Fritts, H.C. Tree Rings and Climate; Academic Press: Cambridge, MA, USA, 1976.

39. Chenorkian, R. Pratique Archéologique Statistique et Graphique; Collection Méthodes et techniques; Editions Errance: Arles, France, 1996.

40. Serre, F. The dendroclimatological value of the european larch (Larix decidua Mill.) in the french maritime Alps. Tree Ring Bull. $1978,38,25-34$.

41. Belingard, C.; Tessier, L. Trees, man and climate over the last thousand years in southern French Alps. Dendrochronologia 1997, 15, 73-87.

42. Tessier, L.; Edouard, J.-L. Longues séries dendrochronologiques à la limite supérieure des forêts dans les Alpes. In La Dendroécologie; Payette, S., Filion, L., Eds.; Presses de l’Université de Laval: Quebec City, QC, Canada, 2010; pp. 683-708.

43. Lebourgeois, F. Réponse au climat du sapin (Abies alba Mill.) et de l'épicéa (Picea abies (L.) Karst.) dans le réseau RENECOFOR. Rev. For. Française 2006, 58, 419-432. [CrossRef]

44. Schweingruber, F.H. Tree Rings. Basics and Applications of Dendrochronology; D. Reidel Publishing Company: Dordrecht, The Netherlands, 1988.

45. Cook, E.R.; Kairiukstis, L.A. Methods of Dendrochronology, Application in the Environmental Sciences; Klumer Academic Publishers, and International Institute for Applied Systems Analysis: Dordrecht, The Netherlands, 1990.

46. Nicault, A.; Bégin, Y.; Guiot, J. Standardisation des séries dendrochronologiques. In La Dendroécologie; Principes, Méthodes et Application; Payette, S., Filion, L., Eds.; Presse de L'université Laval: Quebec City, QC, Canada, 2010; pp. 199-227.

47. Guenet, P. Analyses polliniques en Artense et sur le plateau de Millevaches (Massif Central, France). Palynosciences 1993, 2, 79-107.

48. Pardé, J. Production et sylviculture de l'épicéa commun en plantations. Rev. For. Française 1984, 36, 261-262. [CrossRef]

49. Py, V.; Veron, A.; Edouard, J.-L.; De Beaulieu, J.-L.; Ancel, B.; Segard, M.; Durand, A.; Leveau, P. Interdisciplinary characterisation and environmental imprints of mining and forestry in the upper Durance valley (France) during the Holocene. Quat. Int. 2014, 353, 74-97. [CrossRef]

50. Blanc-Garidel, F.; Wicha, S. Archéologie du bâti et rénovation urbaine. La place de la dendrochronologie. L'exemple de Grasse (Alpes-Maritimes). In ARCADE: «Approche Diachronique et Regards Croisés: Archéologie, Dendrochronologie et Environnement», Actes du Séminaire Interlaboratoires MMSH; Shindo, L., Edouard, J.-L., Suméra, F., Bailly, M., Hartmann, A., Eds.; Editions SRA-DRAC PACA: Aix-en-Provence, France, 2019; pp. 139-149. 
51. Prat, B. Système Agropastoraux et Milieux Périurbains en Basse Auvergne au Cours des Trois Derniers Millénaires: Contribution de L'analyse Palynologique à L'étude des Interactions sociétés-Milieux. Ph.D. Thesis, Université de Clermont-Ferrand 2, Aubière, France, 2006.

52. Walsh, K.; Mocci, F. Driving forces and variability in the exploitation of a high-altitude landscape from the Neolithic to Medieval Periods in the southern French Alps: A Historical Ecology of the Neolithic to Medieval Periods in the Southern French Alps: A reassessment of "driving forces". In Summer Farms: Seasonal Exploitation of the Uplands from Prehistory to the Present; Collis, J., Nicolis, F., Pearce, M., Eds.; Sheffield Archaeological Monographs: Sheffield, UK, 2016; Volume 16, pp. 183-201.

53. Miras, Y.; Mariani, M.; Ledger, P.M.; Mayoral, A.; Chassiot, L.; Lavrieux, M. Holocene vegetation dynamics and first Land-Cover estimaztes in the Auvergne Mountains (Massif Central, France): Keys tolls to landscape management. Interdiscip. Archaeol.-Nat. Sci. Archaeol. 2018, 9, 179-190.

54. Guibal, F.; Pomey, P. Dendrochronologie et construction navale antique. Archéosci. Rev. D'archéométrie 2004, 28, 35-42. [CrossRef]

55. Shindo, L.; Labbas, V.; Edouard, J.-L.; Guibal, F. La construction en mélèze dans les Alpes du Sud depuis le Xe siècle: Une nouvelle lecture dendrochronologique de l'occupation humaine en montagne et des ressources forestières, données et méthodologies inédites. Archéosci. Rev. D'archéométrie 2018, 42, 63-75. [CrossRef]

56. Baratier, E. La Démographie Provençale du XIII au XVIe Siècle, Avec Chiffres de Comparaison Pour le XVIIIe; S.E.V.P.E.N.: Paris, France, 1961.

57. Falque-Vert, H. Les Hommes et la Montagne en Dauphiné au XIIIe Siècle; Presses Universitaires: Grenoble, France, 1997.

58. Le Roy Ladurie, E. Histoire Humaine et Comparée du Climat. T.1, Canicules et Glaciers XIIIe-XVIIIe Siècle; Fayard: Paris, France, 2004.

59. Pécout, T.; Butaud, G.; Bouiron, M.; Jansen, P.; Venturini, A. L'enquête Générale de Leopardo da Foligno en Provence Orientale (Avril-Juin 1333); Editions du Comité des Travaux Historiques et Scientifiques: Paris, France, 2008; pp. 203-206.

60. Ljungqvist, F.C.; Tegel, W.; Krusic, P.J.; Seim, A.; Gschwind, F.M.; Haneca, K.; Herzig, F.; Heussner, K.-U.; Hofmann, J.; Houbrechts, D.; et al. Linking European building activity with plague history. J. Archaeol. Sci. 2018, 98, 81-92. [CrossRef]

61. Burri, S. Vivre de L'inculte, Vivre Dans L'inculte en Basse Provence Centrale à la fin du Moyen Age: Histoire, Archéologie et Ethnoarchéologie d'un Mode de vie Itinérant. Ph.D. Thesis, Aix-Marseille Université, Marseille, France, 2012.

62. Blondel, F.; Labbas, V.; Shindo, L.; Noûs, C. La dendrochronologie: Potentialités et nouveaux enjeux pour l'archéologie. In Bioarchéologie: Minimums méthodologiques, référentiels communs et nouvelles approches: Actes du 4e séminaire scientifique et technique de 1'Inrap, 28-29 November 2019, Sélestat; Carpentier, C.; Arbogast, R.-M.; Kuchler, P., Eds.; on ligne. 2020. Available online: https:/ / hal-inrap.archives-ouvertes.fr/hal-03081687/document (accessed on 20 December 2021).

63. Belingard, C.; Tessier, L. Etude dendroécologique comparée de vieux peuplements de Larix decidua Mill. dans les Alpes françaises du sud. Dendrochronologia 1993, 11, 69-78.

64. Chenard, G.; Galvin-Demoz, M.; Valle de Loro, D. Auprès de Mon Arbre... La forêt Dans les Hautes-Alpes d'y il a Longtemps à Nos Jours, Dossier Thématique des Archives Départementales des Hautes-Alpes; Agence Culturelle du Conseil Général: Gap, France, 2012.

65. Amouric, H. Pratiques et usages de la forêt provençale au Moyen Age. In La Vida Medieval a les Dues Vessants del Pirineu, I $i$ II: $1 r$ Curs D'arqueologia D'ANDORRA del 26 de Setembre al 2 D'octubre de 1988, 2 r curs D'arqueologia d'Andorra del 12 al 23 de Setembre de 1989; Servei d'Arqueologia d'Adorra, Ed.; Andorra Govern: Andorra La Vella, Andorra, 1990; pp. 77-89.

66. Corona, C.; Edouard, J.-L.; Guibal, F.; Guiot, J.; Bernard, S.; Thomas, A.; Denelle, N. Reconstruction des températures estivales dans les Alpes françaises au moyen de données dendrochronologiques (749-2008 AD). In Actes du Colloque Panorama de la dendrochronologie en France, 8,9 et 10 Octobre 2009, Digne-les-Bains, Alpes-de-Haute-Provence; Astrade, L., Miramont, C., Eds.; Collection Edytem, Laboratoire Edytem: Chambéry, France, 2010; Volume 11, pp. 69-76.

67. Fassion, F.; Coursol-Delpy, M.; Argant, J.; Deng-Amiot, Y.; Cubizolle, H. L'évolution de la végétation à l’Holocène récent et l'augmentation de la pression humaine dans le massif volcanique du Cantal (Massif Central, France): L'exemple du vallon du Frau (commune de Chavagnac, Cantal). Quaternaire 2015, 26, 307-321. [CrossRef]

68. Bernardi, P. L'exploitation des forêts. In Forêts Alpines et Charpente de Méditerranée; Bernardi, P., Ed.; Editions du Fournel: L'Argentière-La Bessée, France, 2007; pp. 47-55.

69. Ballut, C.; Prat, B.; Lòpez-Sàez, J.A.; Gaby, G.; Cabanis, M. Evolution environnementale d'une zone humide et de son bassin versant depuis la fin de l'âge du Fer: Le maar de Montchâtre (Massif Central, France). Quaternaire 2008, 19, 69-79. [CrossRef]

70. Violaine, N.; Surmely, F.; Miras, Y. L'évolution des paysages et des architectures sur le planèze sud du Cantal du XIe au XIXe siècle: Apport des données archéologiques, paléoenvironnementales et archivistiques. In Le Paysage Rural au Moyen Âge, Actes du 13e Congrès Nationaux des Sociétés Historiques et Scientifiques; Guillere, C., Ed.; Editions du CTHS: Paris, France, 2012; Volume 135, pp. 79-105.

71. Blondel, F.; Girardclos, O. Approche dendroarchéologique de l'approvisionnement de la ville antique d'Augustonemetum (Clermont-Ferrand-Puy-de-Dôme) en bois d'œuvre et exploitation forestière. Archéosci. Rev. D'archéométrie 2018, 42, 17-33. [CrossRef]

72. Brès, R. La forêt de Boscodon dans l'histoire de l'abbaye, exploitation et commerce du bois, du moyen-âge au XVIIIe siècle, Ouvrage collectif, Archéologie, histoire, architecture. Cah. Boscodon 1985, 3, 82-87.

73. Court-Picon, M. Approches palynologique et dendrochronologique de la mise en place du paysage dans le Champsaur (HautesAlpes, France) à l'interface des dynamiques naturelles et des dynamiques sociales. Thématique, méthodologie et premiers résultats. Archéologie Midi Médiéval 2003, 21, 211-224. [CrossRef] 